\title{
Lung cancer screening: the past, the present and the future
}

Lung cancer has a huge worldwide impact, resulting in an estimated 1.8 million deaths in 2018 (1). It is the leading cause of cancer mortality in men and the 2nd leading cause in women. In the United States, lung cancer remains the leading cause of cancer mortality in both men and women, accounting for over $20 \%$ of cancer-related mortality (2). Despite advances in treatment, the 5 -year survival for lung cancer remains low, at $17 \%$ (2). A large part of this high mortality is the fact that the majority of patients are diagnosed at a late stage. In 2011, the National Lung Screening Trial (NLST) reported a 20\% reduction in lung cancer mortality in high risk individuals with three annual screens with low-dose computed tomography (LDCT) (3). This was the first time that lung cancer screening was found to reduce lung cancer mortality. In Europe, the Nelson trial demonstrated a $24 \%$ reduction in lung cancer mortality in men and $33 \%$ in women (4).

Lung cancer screening has the potential to be one of the most impactful tools in the fight against lung cancer. However, a decade since the publication of NLST, there is still much work to do. It is estimated that only $4 \%$ of those who were eligible undergo LDCT for lung cancer screening (5). These reason behind this low utilization is likely multifactorial, including lack of awareness among both physicians and patients, screening fatigue among physicians, lack of available resources and concerns regarding the risk/benefit ratio.

In this special series on lung cancer screening, we have assembled an outstanding group of authors who are leading experts in the field of lung cancer screening. We will examine where we are now and how we got here, reviewing the evidence behind lung cancer screening, the risks and benefits of screening and the surgical results of screen-detected cancers outside of a clinical trial. We will discuss how we effectively increase the implementation of lung cancer screening, particularly in underserved populations, how to build a quality lung cancer screening program and how to incorporate smoking cessation into screening programs. Finally, we will focus on the possible future of lung cancer screening such as the use of risk prediction models to better determine those with the highest benefit from screening, including possible screening in light or never smokers. We will also examine the use of biomarkers, radiomics and machine learning to help guide the management of indeterminate pulmonary nodules.

I would like to personally thank all of our authors for their important contributions to this series and their expertise in the field of lung cancer. I hope that our readers gain some valuable information and insight into the past, present and future of lung cancer screening.

\section{Acknowledgments}

Funding: None.

\section{Footnote}

Provenance and Peer Review: This article was commissioned by the editorial office, Current Challenges in Thoracic Surgery (CCTS), for the Special Series "Lung Cancer Screening". The article did not undergo external peer review.

Conflicts of Interest: The author has completed the ICMJE uniform disclosure form (available at https://ccts.amegroups. com/article/view/10.21037/ccts-2020-lcs-01/coif). The series "Lung Cancer Screening" was commissioned by the editorial office without any funding or sponsorship. SLS serves as an unpaid editorial board member of CCTS from October 2019 to September 2021 and served as the unpaid Guest Editor of the special series. The author has no other conflicts of interest to declare.

Ethical Statement: The author is accountable for all aspects of the work in ensuring that questions related to the accuracy or integrity of any part of the work are appropriately investigated and resolved.

Open Access Statement: This is an Open Access article distributed in accordance with the Creative Commons Attribution- 
NonCommercial-NoDerivs 4.0 International License (CC BY-NC-ND 4.0), which permits the non-commercial replication and distribution of the article with the strict proviso that no changes or edits are made and the original work is properly cited (including links to both the formal publication through the relevant DOI and the license). See: https://creativecommons.org/ licenses/by-nc-nd/4.0/.

\section{References}

1. Global Cancer Facts and Figures, 4th Edition, American Cancer Society.

2. Siegel RL, Miller KD, Jemal A, Cancer Statistics 2020. CA Cancer J Clin 2020;70:7-30.

3. National Lung Screening Trial Research Team. Reduced lung cancer mortality with low-dose computed tomography screening. N Engl J Med 2011; 365: 395-409.

4. de Koning HJ, van der Aalst CM, de Jong PA, et al. Reduced Lung-Cancer Mortality with Volume CT Screening in a Randomized Trial. N Engl J Med 2020;382:503-13.

5. Jemal A, Fedewa S. Lung cancer screening with low-dose computed tomography in the United States - 2010 to 2015. JAMA Oncol 2017;3:1278-81.

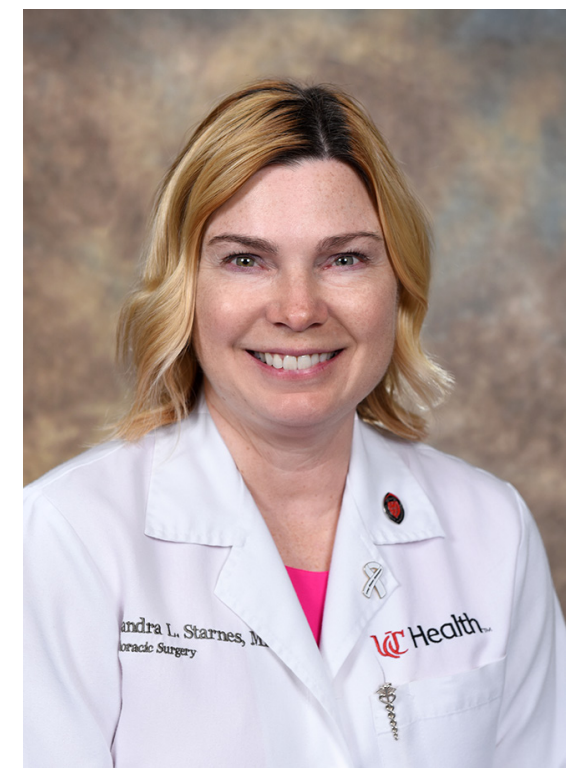

Sandra L. Starnes

Sandra L. Starnes, MD Professor of Surgery, Fohn B. Flege Chair in Cardiothoracic Surgery, University of Cincinnati College of Medicine, Cincinnati, OH, USA.

(Email: starnesl@ucmail.uc.edu)

Received: 03 August 2020; Accepted: 23 August 2020; Published: 25 February 2021. doi: $10.21037 /$ ccts-2020-lcs-01

View this article at: http://dx.doi.org/10.21037/ccts-2020-lcs-01

doi: $10.21037 /$ ccts-2020-lcs-01

Cite this article as: Starnes SL. Lung cancer screening: the past, the present and the future. Curr Chall Thorac Surg 2021;3:1. 